\title{
Prescription Writing Skills of Pre-Clinical Medical and Dental Under- graduate Students
}

\author{
Rauniar GP,' Roy RK, ' Das BP, 'Bhandari G, 'Bhattacharya SK' \\ 'Department of Pharmacology, BPKIHS, Dharan, Nepal
}

\begin{abstract}
Objective of this prospective study was to assess the acquisition of prescribing skill of preclinical medical and dental undergraduate students. Prescription writing skills of 258 students of both first and second year of MBBS and BDS students were analyzed through an objective structured practical examination. MBBS student of second year scored $85.01 \%$ and $92.82 \%$ respectively in physician and drug related component whereas first year MBBS students scored $89.9 \%$ and $83.4 \%$. BDS student of first year scored $91.96 \%$ and $86.33 \%$ in physician and drug related components which is better than second year that scored $83.33 \%$ and $77.94 \%$ respectively. This study revealed that the students of both courses acquire prescribing skills to a limited extent during preclinical phase. Prescribing errors were found both in physician and drug related components. To minimize the different form of prescribing errors vigorous training in the internship period will help to minimize prescribing errors and improve rational prescribing too.
\end{abstract}

Key words: dental, examination, medical, objective, prescription, student

\section{INTRODUCTION}

Prescribing appropriate drugs in correct doses is an important part by which a physician may influence their patient's health. Both oral and written communication skills are important in the daily work of a physician to the patients. Proper prescription writing, which is an essential skill for doctors in medical specialties, is the primary intervention that doctors offer to the suffering humanity. ${ }^{1}$ So, prescribing is one aspect of patient care where it is possible to do considerable harm if not done judiciously. Most junior doctors are unaware of the fact that prescribing errors may contribute to a significant rise in reported hospital adverse events and subsequent medico-legal problems. Unwise prescribing may assume several forms i.e. under, over, inappropriate, irrational and other prescribing errors. ${ }^{2}$ So a budding doctor who is entering the practical field should know how to prescribe safely and correctly and for this the knowledge and understanding, skill and attitude is required by medical graduates. ${ }^{2}$ In this aspect knowledge of Pharmacology is the core component of undergraduate (UG) teaching curriculum when students learn about different drug formulations and the art of prescription writing.

In recent past, the method of teaching and learning processes has been changed to impart the teaching based on therapeutic problem aspect. Concern has also been expressed about various teaching programmes which are not providing thorough knowledge of rational drug prescribing. ${ }^{3}$

\footnotetext{
Correspondence:

Dr. GP Rauniar

Department of Clinical Pharmacology and Therapeutics BPKIHS, Dharan, Nepal.

Phone: +977-25-525555 Ext. 2480

Email: gprauniar@hotmail.com
} 
Problem basedlearning $(\mathrm{PBL})$ is one of the recent instructional methodfor teaching in various medical colleges as it has been recognized world wide.4-6 In Nepal, BPKIHS follows a four and half years integrated problem based, community oriented, organ based unit teaching system in preclinical UG course since 1994.

Prescription writing skill, a part of rational prescribing of drug is being taught in Zero unit. It is the only teaching programme related to the subject.

So the aim of the present study was to identify the basic defects in prescribing skill of both bachelor of medicine and bachelor of surgery (MBBS) and bachelor of dental surgery (BDS) undergraduate students.

\section{MATERIAL AND METHODS}

Prospective study of assessment was conducted amongst first and second year MBBS and Dental students of BPKIHS in between August, 2005 to July, 2006.

After three hours of interactive session (LABEX) in unit zero and also at the end of one unit of teaching programme, the performance in prescription writing skill is assessed through a pharmacotherapy OSPE, involving various stations, each station is of five minutes duration. According to Lofholm and Katzung (2001), the prescription is divided in two broad components: physician related and drug related. ${ }^{6}$

The physician related component is comprised of:

- Prescriber's identity

- Professional degree and registration no.

- Prescriber's address with telephone no.

- Date of prescription

- Patient's Identity

- Patient's address

- The symbol (Rx), "Take Thou"

- Diagnosis of the disease e.g. Bronchial asthma

- Refill information

- Prescriber's signature

The drug related component is comprised of:

- Appropriateness of drug selected

- Strength of drugs

- Dosage form

- Quantity to be dispensed

- Direction for use

Total score of both components was 10 . In which 2.5 score was accounted for physician related components and 7.5 score was distributed for drug related components.

One of the faculty members of the department of Pharmacology assessed prescription writing skill of each student using a check list and score was given accordingly. Each of unit examination consisted of a number of OSPE stations out of which, at least one station comprised of a prescription writing exercise for a particular clinical problem.

The results obtained were statistically analyzed using Chi square test and two tailed students-t test respectively to test the difference between proportion and for continuous variable. $\mathrm{P}$ value $<0.05$ was considered statistically significant.

\section{RESULTS}

The performance of prescription writing skill was assessed amongst a total no. of 258 students, of which 100 were in first year MBBS and 78 in second year MBBS; while 41 in first year BDS and 39 in second year BDS course. Score of different parts of physician and drug related components of both MBBS and BDS students (Table 1-3).

From the result, it is evident that MBBS undergraduate students' score varies from highest $99 \%$ to lowest $84 \%$ among first year and from $100 \%$ to $60.3 \%$ in second year in physician related component (Table 1).

Among the different parts of physician related components, students of second year scored only $60.3 \%$ in patient address and symbol Rx part whereas first year student who scored $85.0 \%$ \& 99.0\% respectively. These differences are statistically significant. Whereas, students of first year scored significantly less only in prescriber's signature part compared to second year's score (Table 1).

On the contrary, first year MBBS students scored $80 \%$ in dosage form and direction for use in drug related component which is statistically significant; this was probably because of their recently acquired knowledge in first year teaching curriculum. Whereas, second year students scored more marks in drug selection and dosage form of drug related component because of the related courses covered in their curriculum and partly due to the clinical aptitude. Based on diagnosis, appropriateness of selection of drug and dosage form were judged against the background knowledge of a particular disease and its correct diagnosis.

But while comparing the total score in individual component, it is seen that students of first year MBBS scored $89.9 \%$ and $83.4 \%$ in physician and drug related 
Rauniar et al. Prescription Writing Skills of Pre-clinical Medical and Dental Undergraduate Students

Table 1. Performance in prescription writing skill amongst first and second year MBBS students

\begin{tabular}{|c|c|c|c|}
\hline \multirow{2}{*}{$\begin{array}{l}\text { S. } \\
\text { No. }\end{array}$} & \multirow{2}{*}{$\begin{array}{l}\text { Component } \\
\text { Physician- related } \\
\text { components }\end{array}$} & \multicolumn{2}{|c|}{ Medical students } \\
\hline & & $\begin{array}{c}\text { First } \\
\text { Year \%) }\end{array}$ & $\begin{array}{c}\text { First } \\
\text { Year \%) }\end{array}$ \\
\hline 1 & Prescriber's identify & 90.0 & $100.0 *$ \\
\hline 2 & $\begin{array}{l}\text { Professional degree and } \\
\text { registration no. }\end{array}$ & 84.0 & 93.6 \\
\hline 3 & $\begin{array}{l}\text { Prescriber's address and } \\
\text { telephone no. }\end{array}$ & 84.0 & 84.6 \\
\hline 4 & Date of prescription & 84.0 & 82.1 \\
\hline 5 & Patient's Identity & 97.0 & 97.4 \\
\hline 6 & Patient's address & 85.0 & $60.3 \dagger$ \\
\hline 7 & Symbol $(R x)$ take & 99.0 & $60.3 \dagger$ \\
\hline 8 & Diagnosis & 92.0 & 97.4 \\
\hline 9 & Refill information & 99.0 & 96.2 \\
\hline 10 & Prescriber's signature & 85.0 & 78.2 \\
\hline \multicolumn{4}{|c|}{ Drug related components } \\
\hline 1 & $\begin{array}{l}\text { Appropriateness of drug } \\
\text { selected }\end{array}$ & 97.0 & 100.0 \\
\hline 2 & Strength of drug & 95.0 & $71.8 \dagger$ \\
\hline 3 & Dosage form & 74.0 & $100.0 \dagger$ \\
\hline 4 & Quantity to be dispensed & 91.0 & 97.4 \\
\hline 5 & Direction for use & 60.0 & $94.9 \dagger$ \\
\hline
\end{tabular}

* $P<0.05 ; \dagger P<0.001$.

component, while second yearMBBS student score $85.0 \%$ and $92.82 \%$ respectively (Table 3 ). The second year MBBS students scored higher marks in drug related part but less in physician related part than the student of first year MBBS (Table 4).

The second year BDS student scored less than 70\% in refill information and prescriber's signature part in physician related component which is statically significant compared to first year (Table 2). Whereas, in drug related component difference of score is significantly more in second year BDS student than that of first year.

The comparison of total score for both physician and drug related component amongst the students of BDS (Table 3). It is seen that second year students scored $83.3 \%$ and $77.94 \%$ in physician and drug related components respectively in comparison to first year's score of $91.96 \%$ and $86.35 \%$.
Table 2. Performance in prescription writing skill amongst first and second year BDS students

\begin{tabular}{|c|c|c|c|}
\hline \multirow{2}{*}{$\begin{array}{l}\text { S. } \\
\text { No. }\end{array}$} & \multirow{2}{*}{$\begin{array}{l}\text { Component } \\
\text { Physician- related } \\
\text { components }\end{array}$} & \multicolumn{2}{|c|}{ Dental students } \\
\hline & & $\begin{array}{c}\text { First } \\
\text { Year (\%) }\end{array}$ & $\begin{array}{c}\text { Second } \\
\text { Year (\%) }\end{array}$ \\
\hline 1 & Prescriber's identify & 97.6 & 94.9 \\
\hline 2 & $\begin{array}{l}\text { Professional degree and } \\
\text { registration no. }\end{array}$ & 87.8 & 79.5 \\
\hline 3 & $\begin{array}{l}\text { Prescriber's address and } \\
\text { telephone no. }\end{array}$ & 87.8 & 89.7 \\
\hline 4 & Date of prescription & 80.5 & 82.1 \\
\hline 5 & Patient's identity & 100.0 & 97.4 \\
\hline 6 & Patient's address & 80.5 & 64.1 \\
\hline 7 & Symbol (Rx) take thou & 100.0 & 100.0 \\
\hline 8 & Diagnosis & 100.0 & 97.4 \\
\hline 9 & Refill information & 97.6 & $84.6 *$ \\
\hline 10 & Prescriber's signature & 87.8 & $43.6 \dagger$ \\
\hline \multicolumn{4}{|c|}{ Drug related components } \\
\hline 1 & $\begin{array}{l}\text { Appropriateness of drug } \\
\text { selection }\end{array}$ & 100.0 & 94.9 \\
\hline 2 & Strength of drug & 87.8 & 84.6 \\
\hline 3 & Dosage form & 87.8 & 53.8 \\
\hline 4 & Quantity to be dispensed & 85.4 & 66.7 \\
\hline 5 & Direction for use & 70.7 & 86.7 \\
\hline
\end{tabular}

${ }^{*} \mathrm{P}<0.05 ; \dagger \mathrm{P}<0.01$. $\mathrm{P}$-value less than 0.05 considered as significant

\section{DISCUSSION}

The study provides an insight into prescription writing skill amongst preclinical MBBS and BDS students. It is quite evident that only a moderate number of students of both the courses are quite aware in every parts physician and drug related components. The second year students made more mistakes in physician related components while students of first year made more mistakes in drug related components (Table 3 ). The probable reason it is due to lack of revision and practice of prescription writing in second year students. Student of first year made more mistakes in dug related part as they are not sufficiently focused on these parts.

Students of second year BDS made more mistakes more in both physician and drug related components than that of first year. Probable explanation of poor performance of second year BDS students is due to the fact that they have to bear the extra burden of additional work load of dental subjects which are taught simultaneously from the second year. 
Rauniar et al. Prescription Writing Skills of Pre-clinical Medical and Dental Undergraduate Students

Table 3. Comparison of scoring rate of different component of prescription between years of MBBS and BDS course

\begin{tabular}{lccc}
\hline Category & No. of student & \multicolumn{2}{c}{ Scoring rate } \\
& & Physician component \% & Drug component \% \\
\hline First year MBBS & 100 & 89.9 & 83.4 \\
Second year MBBS & 78 & 85.01 & 92.82 \\
First year BDS & 41 & 91.96 & 86.34 \\
Second year BDS & 39 & 83.33 & 77.94 \\
\hline
\end{tabular}

In the present study we find both prescribing error and under prescription which support by the study done by Benzamin and Sequeira et al..$^{7,8}$

\section{CONCLUSION}

Evaluation of prescription writing skills in integrated teaching is an important part of teaching and learning method where students can be focused more to clinical pharmacology and therapeutics and improved their prescribing skills. This type of evaluation should be included in undergraduate medical and dental curriculum to find out the defects among students.

However outgoing students should also included in this type of evaluation and a vigorous training in the internship period will help to minimize prescribing errors and improve rational prescribing too.

\section{ACKNOWLEDGEMENT}

The authors are grateful to Ms. Rusha Tamrakar and Mr. Gokarna Bhandari for their secretarial and technical support.

\section{REFERENCE}

1. Maxwell S, Walley T. Teaching safe and effective prescribing in UK Medical schools: a core curriculum for tomorrow's doctors. Br J Clin Pharmacol 2003;55:496-503.

2. Aronson JK. A prescription for better prescribing. Br. J Clin Pharmacol 2006;61(5):487.

3. Audit commission 2001 A spoonful of sugar- improving medicines management in hospital. Audit commission (http://www.audit-comission.gov.uk/publication/ spoonful-sugar.html)

4. de Vries TPGM, Henning RH, Hogerzeil HV, Fresle DA. Guide to good prescribing: A Practical Manual World Health Organization Action Programme on Essential Drug Geneva 1994:56-61.
5. Vestal RE, Benowitz NL. Workshop on problem based learning as a method for teaching Clinical Pharmacology and Therapeutics in medical schools. J Clin Pharmacol 1992;32:779-97.

6. Lofholm PW, Katzung BG: Rational prescribing and prescription writing: In Katzung BG editor. Basic and Clinical Pharmacology. New Yourk: Mc Graw-Hill; 2001. p. 1104-113.

7. Benzamin DM. Reducing medication errors and increasing patient safety. Care studies in clinical Pharmacology. J Clin Pharmacol 2003;43:768-83.

8. Sequeira RP, A Ansari TM, Al Khaja KAJ. Prescription errors in primary care: types, determinants and therapeutic implication. Drug Saf 2004;26:959. 